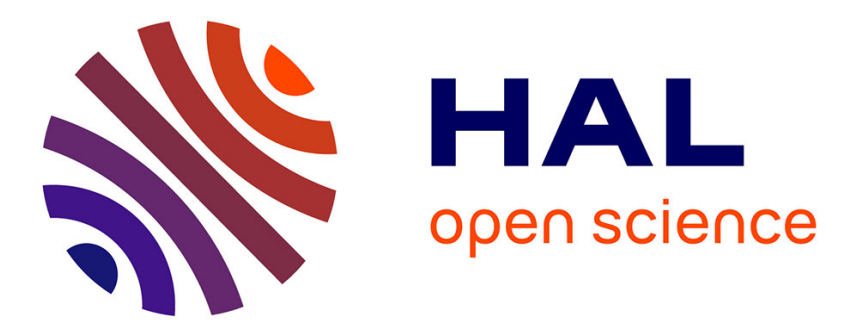

\title{
Correction to "Flux Control Range Broadening and Torque Ripple Minimization of a Double Excitation Synchronous Motor" [Jan 17 Art. no. 8100510]
}

Trung-Kien Hoang, L. Vido, M. Gabsi, F. Gillon

\section{- To cite this version:}

Trung-Kien Hoang, L. Vido, M. Gabsi, F. Gillon. Correction to "Flux Control Range Broadening and Torque Ripple Minimization of a Double Excitation Synchronous Motor" [Jan 17 Art. no. 8100510]. IEEE Transactions on Magnetics, 2017, 53 (5), pp.1 - 1. 10.1109/TMAG.2017.2661240 . hal-01657422

\section{HAL Id: hal-01657422 \\ https://hal.science/hal-01657422}

Submitted on 6 Dec 2017

HAL is a multi-disciplinary open access archive for the deposit and dissemination of scientific research documents, whether they are published or not. The documents may come from teaching and research institutions in France or abroad, or from public or private research centers.
L'archive ouverte pluridisciplinaire HAL, est destinée au dépôt et à la diffusion de documents scientifiques de niveau recherche, publiés ou non, émanant des établissements d'enseignement et de recherche français ou étrangers, des laboratoires publics ou privés. 


\section{Erratum}

\section{Correction to "Flux Control Range Broadening and Torque Ripple Minimization of a Double Excitation Synchronous Motor"}

K. Hoang ${ }^{1}$, L. Vido ${ }^{2}$, M. Gabsi ${ }^{1}$, and F. Gillon ${ }^{3}$

${ }^{1}$ Systèmes et Applications des Technologies de l'Information et de l'Energie, Ecole normale supérieure de Cachan, 94235 Cachan, France

${ }^{2}$ Systèmes et Applications des Technologies de l'Information et de l'Energie, Université de Cergy-Pontoise, 95000 Cergy-Pontoise, France

${ }^{3}$ Laboratoire Energétique, Electronique et Procédés, Ecole Centrale de Lille, 59650 Villeneuve d'Ascq Cedex, France

N [1], an error in Fig. 2 in Section II-B is corrected. In the original figure, Fig. 2(b) was exactly the same as Fig. 2(a). The correction is shown here.

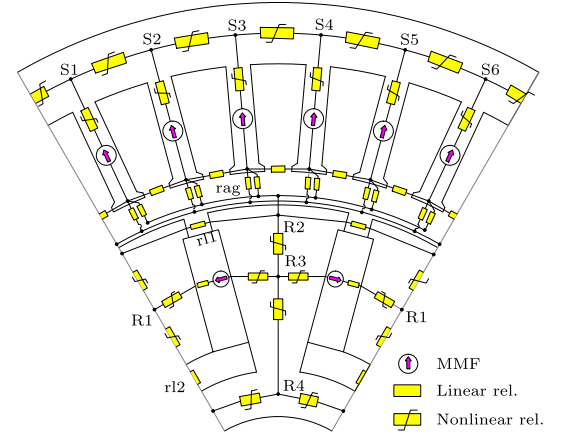

(a)

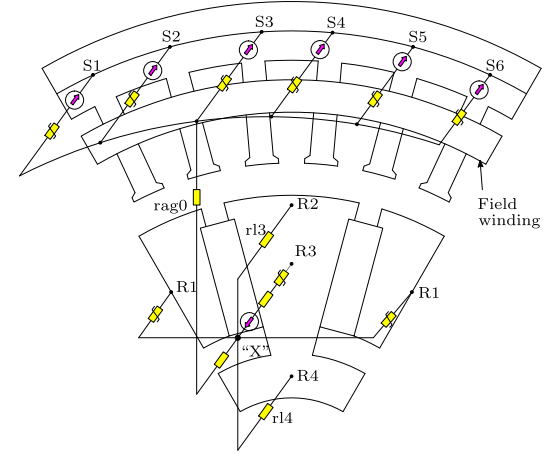

(b)

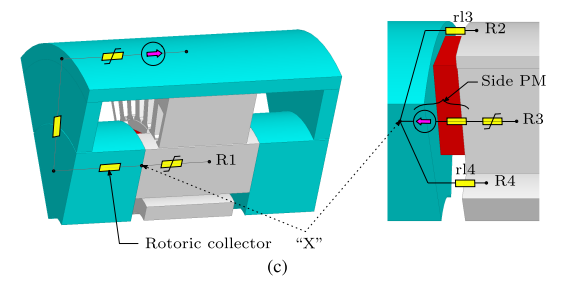

Fig. 2. RN model of the prototype. (a) First part. (b) Second part. (c) More details about elements in the axial direction.

\section{REFERENCES}

[1] K. Hoang, L. Vido, M. Gabsi, and F. Gillon, "Flux control range broadening and torque ripple minimization of a double excitation synchronous motor," IEEE Trans. Magn., vol. 53, no. 1, Jan. 2017, Art. no. 8100510.

Manuscript received January 13, 2017; accepted January 25, 2017. Date of current version April 17, 2017. Corresponding author: T.-K. Hoang (e-mail: kienht26@gmail.com).

Color versions of one or more of the figures in this paper are available online at http://ieeexplore.ieee.org.

Digital Object Identifier 10.1109/TMAG.2017.2661240

0018-9464 @ 2017 IEEE. Personal use is permitted, but republication/redistribution requires IEEE permission. See http://www.ieee.org/publications_standards/publications/rights/index.html for more information. 